Polgári Szemle, 15. évf. 1-3. szám, 2019, 431-438., DOI: 10.24307/psz.2019.0929

Szöllősi Tamás

\title{
A helymarketing és településfejlesztés kutatottsága tudománymetriai szempontból
}

\section{Scientometric Research of Place Marketing and Community Development}

\section{ÖSSZEFOGLALÁS}

A települések fejlődése, versenyképességük megtartása szempontjából elengedhetetlen, hogy megfelelô marketingstratégiákhoz nyúljanak. Ez a tudományterület még igen kiaknázatlan Európa számos országában, de fóleg Románia és Magyarország viszonylatában, ezért fontos, hogy megvizsgáljuk, hol tart ez a kutatás, és mi a fó diskurzus. Fellapozva a szakirodalmat, nem találunk hasonló kutatásokat, amelyek tudománymetriai szempontjából mérik a különbözó országokat, szerzôket kulcsszavak után. Ezeket az adatokat elemzi a kutatás, irányvonalakat mutatva, motiválva a szerzôket még több kutatásra a témában.

Kulcsszavak: társadalomtudomány, tudománymetria, településfejlesztés, helymarketing, városmenedzsment, városkép

\section{SUMmaRY}

In order for communities to develop and maintain their competitiveness, it is essential that they use appropriate marketing strategies. In many countries in Europe this field of science is still very unexploited, but especially in Romania and Hungary, so it's important to examine where this research is going and what is the main discourse. Searching the literature, we do not find similar research that measures different countries, authors, and keywords in terms of scientometrics. The research analyzes these data, showing guidelines and motivating authors to do more research on the subject.

Keywords: social sciences, scientometrics, community development, place marketing, urban management, urban image

SzÖllốsi TAMÁs, doktorandusz hallgató, NKE - Sapientia EMTE, Közigazgatás-tudományi Doktori Iskola (office.szollosit@gmail.com). 


\section{Tudományos múhely}

\section{Bevezetó}

A települések egyre nagyobb hangsúlyt fektetnek a versenyképességük, eladhatóságuk fejlesztésére. Ez viszonylag új szakterület a településtan, a marketing és a turizmus határvonalán. „A közigazgatási jog - ahol az önkormányzati törvények egyáltalán megemlítik ezt a fogalmat általában a helyi önkormányzatok, a helyhatóságok kompetenciájába utalja a település »eladásával « kapcsolatos feladatokat, tevékenységeket" (Tózsa, 2014). Európában több országban megfigyelhetốk a helymárkázási tevékenység, régiók, települések erôforrásokat különítenek el, és jól megkonstruált stratégiákkal sikeres fejlesztéseket eszközölnek, amelyek segítik a településeket a fejlódésben, illetve a versenyképességben. „A helyi arculat kialakítása - ha magától nem alakult ki a történelem során - a mindenkori helyhatóság feladata, mint ahogy a településmarketing, kompetenciamarketing, ami annyit tesz, hogy a helyi, a területi önkormányzat, illetve országos szinten a kormány felelôssége a településsel, a régióval, illetve az országgal kapcsolatos arculat hivatalos megfogalmazása, kommunikációja” (Tózsa, 2013b).

Romániában és Magyarországon ezek a folyamatok még gyerekcipóben járnak. Az elmúlt tíz évben több településen elindultak, és a megfelelố marketinstratégiák jól mérhetô, pozitív eredményeket hoztak. Fontos, hogy ismerjük ezeket a stratégiákat, és tudományosan kutassuk, miáltal irányvonalakat mutathatunk azon településeknek, ahol még nem indultak el, vagy még nagyon az elején tartanak a helymarketingtervek megfogalmazása.

Manapság rengeteg, szinte feldolgozhatatlan mennyiségú információ áll a kutatók rendelkezésére a különbözó tudományterületeken, így a helymarketing, településfejlesztés témákörében is. Nemzetközi szinten több kutató foglalkozik ezzel a kérdéskörrel, ám fontos megvizsgálni, hogy kik azok, akik kiemelkedően publikálnak, és fenntartják a folyamatos diskurzust. Erdélyi magyarként fontos megvizsgálnunk, hol tart a tudomány kutatottsága Európában, Romániában és az anyaországban.

A kutatás során több kérdésre kerestük a választ. Mennyire kutatott a téma globális szinten? Mennyire kutatott a társadalomtudományok terén? Hol áll Európa ebben a kutatásban? És talán a legfontosabb és legrelevánsabb, hogy Romániában és Magyarországon milyen szinten áll a kutatottsága? A három tétel, melyekre igazolást keresünk:

1. Általános és társadalomtudományok terén, globális szinten több kutató is foglalkozik a témával.

2. Európa vezetó pozíciót foglal el ezekben a kutatásokban.

3. Magyarországon és Romániában a téma kutatása még igencsak gyerekcipóben jár.

\section{ELMÉLETI HÁTTÉR}

A tudományos tevékenység vizsgálata különbözố tudományterületek szintjén nem új keletú. Ami jelen kutatást megkülönbözteti az interneten fellelhetô más kutatásoktól, az az irányított kulcsszó szerinti kutatás, illetve a földrajzi behatárolás. A világhálón való szabad keresés, valamint a szakosított kutatási adatbázisok lekérdezése alapján ennek ellenére kijelenthetô, hogy a helymarketing és településfejlesztés társadalomtudományokban végzett kutatói és publikációs tevékenysé- 


\section{Tudományos múhely}

gének feltérképezése egyedülálló, hiánypótló és elốzmény nélküli.

A jelen kutatás eredményeinek értékelése, valamint a következtetések alapján, az adatok hasznosítása és a kutatás folytatása előtt, mindenképpen érdemes vizsgálni a hasonló jellegú kutatatásokat.

Ha fellapozzuk a szakirodalmat, több cikket is találunk a településmarketing tudományára vonatkozóan (Tózsa, 2013a), valamint többnyire az információtermelés mértékére (Tolnai, 2008) vagy az egyes intézmények publikációinak értékelésére (Vinkler, 2006). A vizsgálatok kimutatták például, hogy a tudományos kutatások szerkezete és száma Romániában és Magyarországon jelentôsen eltér az európai átlaghoz képest, ahol a tudományos kutatás nagyobb szerepet játszanak. „A tudománymetria a szakirodalom információinak (folyóiratcikkek, szabadalmak) elemzése révén nemcsak a múltbeli, illetve jelen állapotok »tudományos témáinak térképét « tudja felrajzolni, hanem idôbeni adatsorok vizsgálata révén új szakterületek születését, illetve már múködő kutatások fejlôdését, stagnálását, visszafejlődését is képes jelezni. Az egyes témák, kutatóhelyek, országok kapcsolatainak erôsségét a publikációk, hivatkozások és idézetek számának elemzése révén tárhatjuk fel" - írja Vinkler Péter a $M a$ gyar Tudományban megjelent cikkében (Vinkler, 2008).

Ahogy az a fentiekből is kiderül, a tuományos diszkurzus megrajzolása szempontjából elengedhetetlen számszerú összefüggésben vizsgálni a különbözô földrajzi területek és tematikák megoszlását. A helymarketing kutatása újszerú tematika, ezért rengeteg kiaknázatlan lehetôséget nyújt a kutatók számára. A jelen kutatás a kezdeti szakaszában arra a kérdésre keresi a választ, hogy egy tudományterületen belül milyen arányban vesznek részt az európai, magyarországi és romániai kutatók a kutatásokban és publikációs tevékenységben.

\section{MódszerTAN}

A kutatáshoz elengedhetetlen a Scopus keresômotorjának használata, amely a lektorált irodalom legnagyobb adatgyújteménye, az itt fellelhetô adatok elemzésére támaszkodik a tanulmány. A vizsgálat elsố körben globális szintre terjedt ki, majd ezt szúkítettük a társadalomtudomány területére, illetve tovább szúkítve Romániára és Magyarországra. A Google keresômotorját vagy a Web of Science-t használva, fellelhetốk egyéb releváns kutatások is, ugyanakkor kevés társadalomtudományi cikket találunk, szemben a Scopus kiterjedt adatbázisával, amely 2004 novembere óta átfogó képet ad a világ tudományos kutatási teljesítményérôl minden tudományágban. Az adatbázis 1966-ig visszamenóleg több millió kivonatot tartalmaz, és naponta bôvül. A Scopus hátrányai közé tartozik, hogy ingyenesen nem hozzáférhetô, regisztrált hálózaton kívül nem használható.

A kutatást a helymarketing és településfejlesztés területe négy kulcsszavának direkt keresésével végeztük, melyek a következók: place branding ${ }^{1}$, place marketing $^{2}$, urban management ${ }^{3}$, urban image . $^{4}$. Ezek esetében a 2000 és 2017 közötti idôintervallumban megfigyelhetô adatokat elemeztük. Elsố lépésben a kulcsszavakat vizsgáltuk nemzetközi viszonylatban, itt különös figyelmet fordítottunk a publikációk számára, ezek évenkénti növekedésére, adott esetben csökkenésére, megfigyeltük az elsố öt országot a publikációk 


\section{Tudományos múhely}

származási helyét illetôen, a legrelevánsabb szerzóket, ezek egymás közti viszonyát, elemeztük a publikációk fajtáját, majd a tematikai elosztását. Ezután mindegyik tematikánál a kör szúkítése következett, csak a társadalomtudományokra, ám ugyancsak nemzetközi szinten. Majd a kört tovább szúkítettük Romániára és Magyarországra, és a fent említett paraméterek szerint elemeztük. A két ország esetében az intézményi elosztást is figyeltük.

\section{EREDMÉNYEK}

A place branding kulcsszót vizsgálva a keresô 1268 dokumentumot adott, országok tekintetében az elsố helyeken az Egyesült Királyság, Amerikai Egyesült Államok, Ausztrália, Hollandia és Kanada áll. Az évek szerinti elosztás szempontjából emelkedô tendencia figyelhetó meg. Társadalomtudományokban 592 dokumentumot talált a rendszer, hasonló évenkénti emelkedô tendenciával. Az országok eloszlása itt a következóképpen alakult: Egyesült Államok, Nagy-Britannia, Hollandia, Ausztrália és Kanada. Romániában 18 dokumentum, míg Magyarországon két publikáció található. A következô, place marketing kulcsszó vizsgálatakor 7736 dokumentum volt fellelhetô, a publikációk esetében folyamatos, kisebb léptékú növekedés fedezhetô fel. Országok tekintetében az Amerikai Egyesült Államok vezet, utána Anglia, Ausztrália, Németország és Franciaország sorakozik fel. A társadalomtudományok tematikában 1746 dokumentum lelhetô fel, ahol a növekedési tendencia az elóbbiekhez hasonló. Országok tekintetében az USA, Anglia, Ausztrália, Kanada és Németország áll a lista elején. Romániai viszonylatban 9 dokumentum található, amelyek nagy része 2011, 2013-ban jelent meg, 2017-ben további két írás. Magyarországot tekintve öt bejegyzés található. $\mathrm{Az}$ urban management kulcsszó 3136 találatot eredményezett, melyekbôl a legtöbb az Amerikai Egyesült Államokhoz köthetô, ezt követi Nagy-Britannia, Ausztrália, Kína és India. A dokumentumok eloszlására egy többnyire folyamatosan emelkedố tendencia jellemzô. 2012 után rendszeresen 200 fölött van az évenkénti publikációk száma, 2017-ben 260 írást jegyeztek. A társadalomtudományok témakört tekintve, 1152 dokumentumot talált a Scopus keresôje, itt szintén folyamatos emelkedést mutat a görbe. Az országok listáján az élen Amerika áll, majd Anglia, Ausztrália, Kanada és Németország. A kulcsszó tekintetében Romániában és Magyarországon egyaránt 3-3 publikációt jegyeztek. Az urban image kulcsszó kutatása során, a vizsgált idôintervallumban 20344 bejegyzés született, amelyek emelkedô tendenciát mutatnak, 2017-ben 2040 dokumentumot publikáltak. Országok eloszlásában Kína jár az élen, ôt követi az USA, Németország, Franciaország és Olaszország. Társadalomtudományok terén 5206 dokumentum született a vizsgált idôintervallumban, amelyból 601 2017-ben. Országok viszonylatában az elsố helyen az Amerikai Egyesült Államok áll, majd Kína, Anglia, Németország és Franciaország következik a sorban. Romániában 41 dokumentum, míg Magyarországon 17 dokumentum található.

Ha a négy kulcsszót összevetjük az országok szerinti eloszlással, az Amerikai Egyesült Államokban jelenik meg a legtöbb publikáció a társadalomtudományokban, emellett az Egyesült Királyságban, Ausztráliában, Kanadában és Né- 


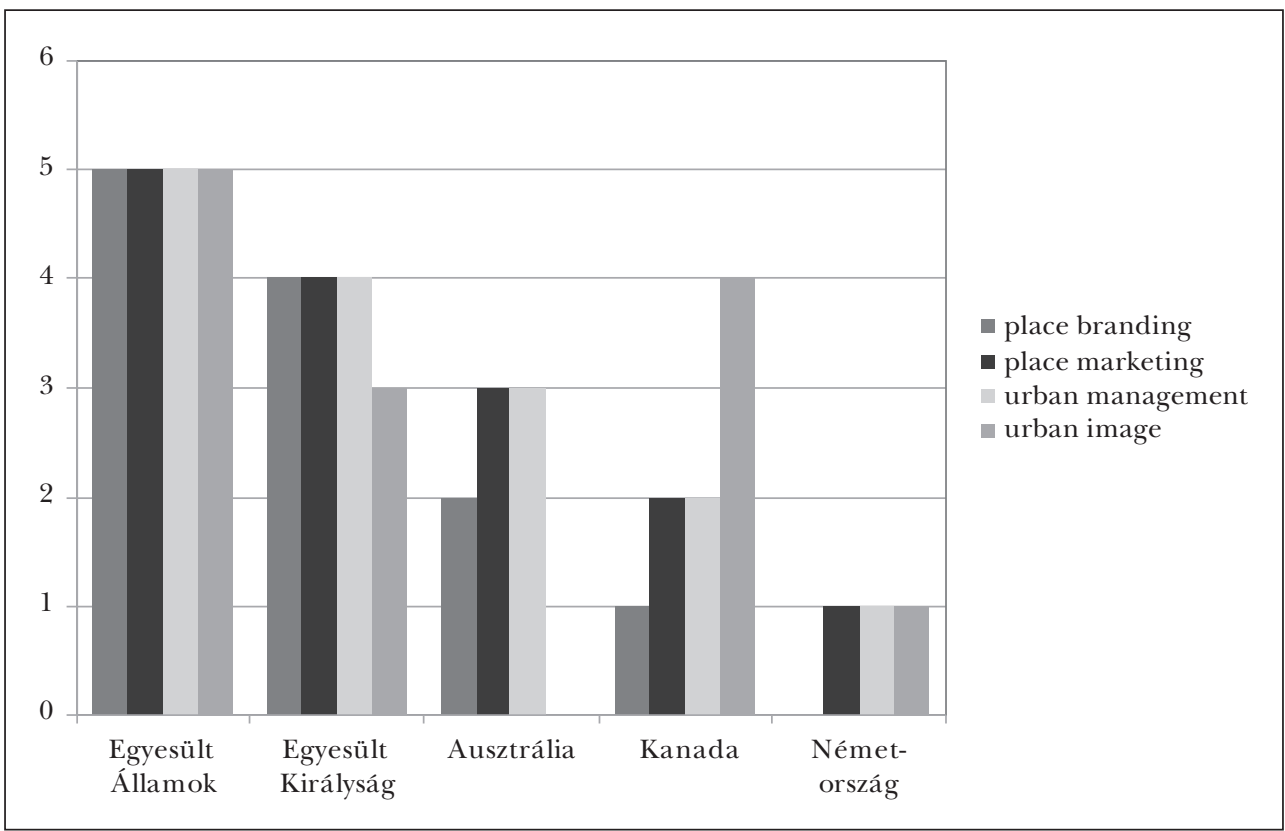

Forrás: Saját szerkesztés

metországban publikálnak túlnyomórészt. Országok szerinti bontásban az elsố három kulcsszó többnyire hasonló eredményt adott, az utolsó, az urban image kutatásánál volt eltérést, megjelent Kína és Franciaország, de Amerika, Anglia és Németország itt ugyancsak jelen van (1. ábra). Világviszonylatban az elsô 5 helyen két európai ország is található, így kijelenthetô, hogy Nyugat-Európa irányadó a tematizálásban.

A 2. ábra azt mutatja, hogy mely szerzôk publikáltak leggyakrabban az adott témában. Itt négy nevet említhetünk: Ares Kalandides, Mihalis Kavaratzis, Gary Warnaby és Sebastian Zenker. Tematikánként ugyan váltogatják a helyüket, de az elsố öt, legtöbbet felmerüló szerzô közt folyamatosan jelen vannak. Legaktívabb közülük is Mihalis Kavaratzis. Itt is megfigyelhetô, hogy míg az elsố három kulcsszó hasonló eredményeket adott, a negyediknél nagy eltérések mutatkoznak. Az urban image kulcsszó tekintetében más szerzóket mutatott a keresômotor, itt a leggyakrabban publikáló szerzô Peter Reinartz. Ebben a tematikában a többi név közül senki nem jelenik meg az elsố öt leggyakrabban publikáló szerzô közt.

Ares Kalandides a Manchester Metropolitan University, Institute of Place Management professzora, amely egyetem a világranglistán a 601-800. helyen áll jelenleg. A szerzôtól 29 dokumentum található a Scopusban, h-indexe 13, 556 alkalommal idézték. Legtöbb publikációja a Journal of Place Management and Developmentben jelent meg, amely Q2-es besorolású. Mihalis Kavaratzis az egyesült királyságbeli University of Leicester tanára. Az egyetem a 167. helyen áll a 


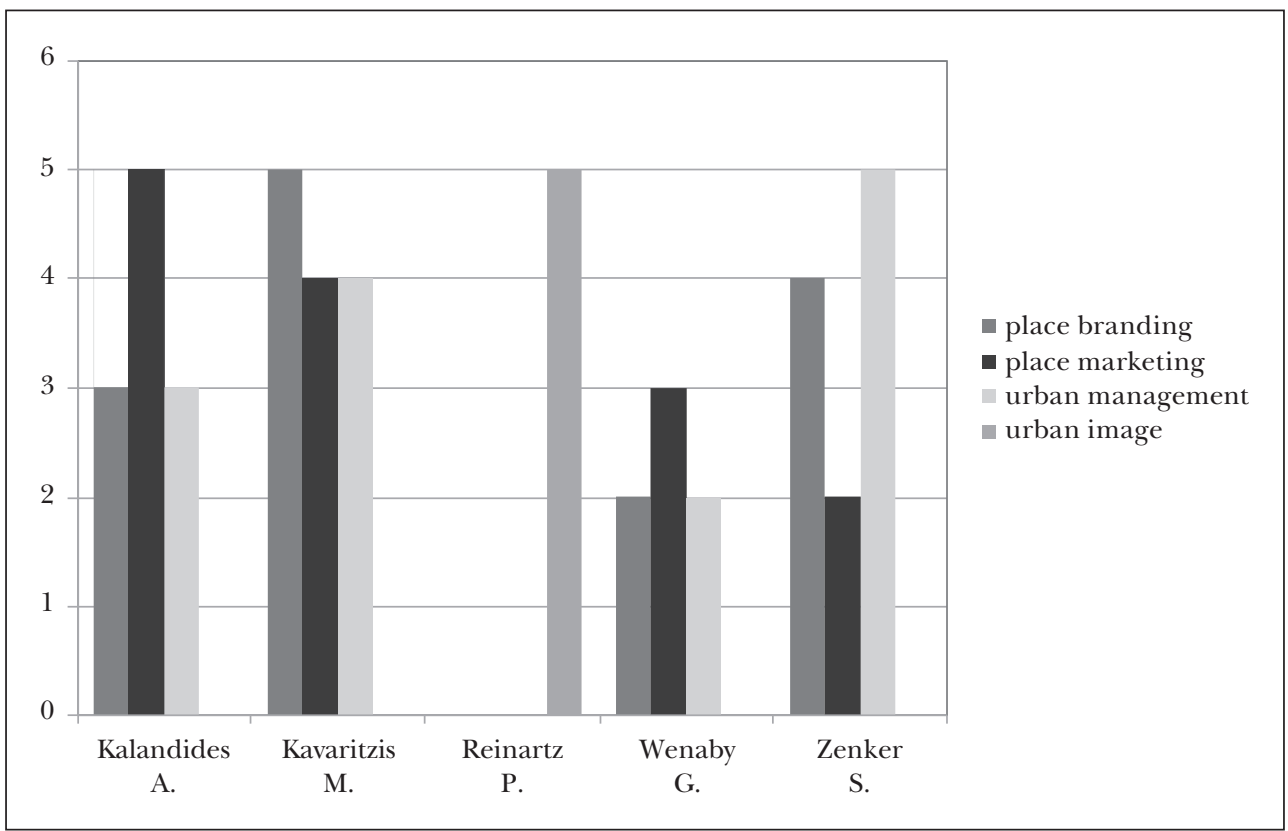

Forrás: Saját szerkesztés

ranglistán. Kavaratzisnak 38 publikációja található a Scopusban, 14-es hindexszel, 1330 idézéssel. Legtöbb publikációja szintén a Journal of Place Management and Developmentben jelent meg. Gary Warnaby szintén a Manchester Metropolitan University, Institute of Place Management tagja, 81 publikációja született, amelyeket 1081 alkalommal idézték, a h-indexe 19-es. Legtöbb publikációja a Q1-es besorolású International Journal of Retail and Distribution Managementben jelent meg. Sebastian Zenker a dániai Copenhagen Business School, Department of Marketing professzora, az iskola a 201-250. helyen áll a világranglistán. 30 dokumentum található a neve alatt, 1081 alkalommal idézték, és 15-s h-indexe van. Legtöbbet a Journal of Place Management and Developmentben publikált.

\section{Románia és Magyarország}

Román és magyar viszonylatban nem mondható reprezentatívnak a publikációk száma, világosan kitúnik, hogy a téma még gyerekcipóben jár ebben a térségben. Ugyanakkor pozitívumként említhetô, hogy születtek publikációk az elmúlt idôszakban, ebbôl következik, hogy elindult a párbeszéd, és kutatják a témát. A romániai publikációkban Luminița Filimon, Dănuț Petrea, Rodica Petrea, Paul Emil Olău szerzôk neve tûnik fel a legtöbb alkalommal.

Luminița Filimon a nagyváradi egyetem tanára (Universitatea din Oradea, Department of Geography), az egyetem a világranglistán nem jegyzett. A szerzố neve alatt 6 dokumentum található a Scopusban, 6 alkalommal idézték, és 2-es h-indexszel rendelkezik. Dănuț Petrea a 


\section{Tudományos múhely}

kolozsvári Babeș-Bolyai Tudományegyetem (Universitatea Babeș-Bolyai Cluj-Napoca, Faculty of Geography) tagja, amely egyetem a 801-1000. helybesorolást kapta a világranglistán. Petrea D 22 publikált dokumentummal, 6 idézéssel és 4-es h-indexszel rendelkezik a Scopus keresóje szerint. Rodica Petrea ugyancsak a nagyváradi egyetem (Universitatea din Oradea, Faculty Geography Tourism and Sport) tagja, 6 dokumentuma lelhetô fel, ezeket 5 alkalommal idézték, és 1-s h-indexszel rendelkezik. Paul Emil Olău szintén a nagyváradi egyetem földrajz, turizmus és sport fakultásának tagja, 3 dokumentumot publikált, 5 idézéssel, és h-indexe az 2-es. A négy szerzó többnyire a Transylvanian Revies of Administrative Sciences-ben publikál, amely Q3-as besorolást kapott.

Magyarországi viszonylatban nehezebb kiemelni a fontos kutatókat, hiszen kevésbé ismétlódnek a nevek. A korábban említett Mihalis Kavaratzis és Udvarhelyi Gergely neve tûnik fel több alkalommal, valamint Kovács Krisztina és Kovács Zoltán egy-egy alkalommal. Udvarhelyi Gergely a Magyar Tudományos Akadémia tagja, egy dokumentum lelhetô fel tôle (társszerzôként) a Scopusban, amelynek még nincs idézése, és h-indexszel sem rendelkezik. A publikáció a Földrajzi Értesítóben jelent meg, amely 2009 után Hungarian Geographical Bullentin néven jelenik meg Q2-es besorolással. Kovács Krisztina a budapesti Bagazs Public Benefits Association (BAGázs) tagja, egy dokumentummal rendelkezik, amely többszerzôs, jelenleg nincs idézése és h-indexe. A publikációja a Journal of Organisational Transformation and Social Change címú lapban jelent meg, amely Q2-es értékelésú. Kovács Zoltán a Magyar Tudományos Akadémia Földrajztudományok osztály tagja, 55 dokumentummal rendelkezik, amelyeket 108 alkalommal idéztek, 13-as h-indexszel rendelkezik. Több alkalommal is publikált a Hungarian Geographical Bulletinbe.

\section{Összegzés}

A fenti adatokból kiderült, hogy nemzetközi szinten nagy mennyiségú publikáció született a vizsgált idôszakban (20002017). A négy kulcsszó releváns információkat biztosított a témáról, a place branding, place marketing és urban management szavakra vonatkozó kutatás felrajzolta a főbb szerzőket, akik kiemelkedóek a kutatási téma területén. A nyugat-európai országok elókelô pozíciót foglalnak el a téma kutatásában úgy a társadalomtudományok, mint összes terület szintjén. A kutatás során sikerült vázolni, hogy a nemzetközi szerzók Európa neves egyetemeiről publikálnak, a szerzók idézettsége is magas, és a lapok besorolása is kiemelkedó, így levonható a következtetés, hogy a szakmailag is elismert a téma.

A romániai szakirodalom jóval szerényebb, ám még mindig reprezentatívak tekinthetô. Több szerzô foglalkozik a témával, jó néhány publikáció is megjelent, Q3-as besorolású lapokban, idézettségük nem kiemelkedô. A szakma részérôl kisebb az elismertségük a nemzetközi kutatókkal szemben, de nem elhanyagolhatók, így adódik a következtetés, hogy kutatás szempontjából ez még kiaknázatlan területnek számít.

Magyarország tekintetében jelenleg a téma nem mondható ismertnek. Kevés szerzố található, ám említésre méltó, hogy a magyar szerzók nemzetközi szerzôkkel dolgoznak közös publikációkban, ez elôsegíti szakmai elismerésüket. A fellelt publikációk Q2-es besorolásúak, 


\section{Tudományos múhely}

amely arra enged következtetni, hogy van aktualitása a téma kutatásának, és felkeltette a szakma figyelmét.

Az urban image kulcsszót nem adott reprezentatív eredményeket, ám a kutatásból nem zárható ki, hiszen a területbe tartozik.

A tanulmány célja a reális adatok azonosítása, a téma aktualitásának felmérése, azon szerzók meghatározása, akik a tudományos diskurzust irányítják, ugyanakkor cél a romániai és magyarországi kutatók motiválása, a témában való publikációkra ösztönzése. A késôbbiekben vizsgálat tárgya lehet a romániai szcéna, a kisebbségi, jelen esetben, magyar kutatók szemszögéból. Erdélyi magyar kutatóknak nagy lehetőséget rejt a kutatási téma, hiszen a román kollégák közt nem találunk magyar szerzốt, amely pluszmotivációt ad, és a kutatás relevanciáját növeli.

\section{JEGYZETEK}

1 A földrajzi területek (régió, település stb.) márkázási tevékenységének megnevezése az angol szakirodalomban a place branding, amelynek magyar megfelelôje a helymárkázás. A helymárkázás a helyi közösségre, identitásra, valamint a turistákra, a hely imázsára koncentrál, kiemelten kezeli a kapcsolatépítést.

2 Különbözô közigazgatási egységek (községek, városok, megyék) piacközpontú településpolitikai megközelítése. A 1970-es évektôl terjedt el a különbözố nyugat-európai és amerikai országokban, majd Kelet-Európa országaiban is egyre többet foglalkoztak a kérdéssel. Az angol szakirodalom a place marketing összefoglaló kifejezést használja.

3 A városmenedzsment kifejezés számos funkciót foglal magában. A város alapvetô funkciója az, hogy a lakosságnak élhetô környezetet biztosítson: menedéket, megélhetést, szórakozást, élelmet és egyéb lehetôségeket az egészséges életmódhoz. Ahhoz, hogy az emberek egzisztenciálisan jól érezzék magukat, a gazdasági, infra- strukturális, egészségügyi és kulturális tényezôknek összhangban kell lenniük.

4 A városkép a település jellegzetes arculata. Jelenti a településrốl alkotott vizuális képzetet és az összbenyomást.

\section{FELhasZnÁlt IRODALOM}

Gupta, Brij Mohan - Dhawan, S. M. - Gupta, Ritu (2015): Internet of Things: A Scientometric Assessment of Global Output, 2005-2014. Journal of Scientometric Research, Vol. 4, No. 2, https://doi.org/10.4103/2320-0057.167248.

Lencsés Ákos (2018): Tudománymetriai mérôszámok, publikációs stratégiák. Open access. Konferencia-előadás, ELTE, Budapest.

Tolnai Márton (2008): Tudósaink mérhetô teljesítménye az MTA Köztestületi Publikációs Adattár adatainak tükrében. Magyar Tudomány, 169. évf., 8. sz., 976-988.

Tózsa István (2013a): Településmarketing. In: Jeney László - Kulcsár Dezsô - Tózsa István (szerk.): Gazdaságföldrajzi tanulmányok közgazdászoknak. Budapesti Corvinus Egyetem - Nemzetgazdasági Minisztérium, Budapest, 89-104.

Tózsa István (2013b): Helyi identitástudat a településmarketingben. Turizmus Online, június 12., http://turizmusonline.hu/aktualis/cikk/helyi_identitastudat_a_telepulesmarketingben.

Tózsa István (2014): A településmarketing elmélete. In: Tózsa István (szerk.): Turizmus és településmarketing. Budapesti Corvinus Egyetem E-Government Alapítvány, Budapest, 129-158.

Vinkler, Péter (1997): Relations of Relative Scientometric Impact Indicators. The Relative Publication Strategy Index. Scientometrics, Vol. 40, No. 1, 163-169, https://doi.org/10.1007/bf02459266.

Vinkler Péter (2006): Composite Scientometric Indicators for Evaluating Publications of Research Institutes. Scientometrics, Vol. 68, No. 3, 629-642, https://doi.org/10.1007/s11192006-0123-z.

Vinkler Péter (2008): Tudománymetriai kutatások Magyarországon. Magyar Tudomány, 169. évf., 11. sz., 1372-1380.

Zsindely Sándor - Schubert András - Braun Tibor (1982): Editorial Gatekeeping Patterns in International Science Journals. A New Science Indicator. Scientometrics, Vol. 4, No. 1, 57-68, https://doi.org/10.1007/bf02098006. 